\title{
Rethinking the Ecosystem Functions of Dicranopteris, a Widespread Genus of Ferns
}

\author{
Long Yang ${ }^{1}$, Yuhui Huang ${ }^{2}$, Lucas Vieira Lima ${ }^{3}$, Zhongyu Sun ${ }^{1}$, Meijie Liu', Jun Wang ${ }^{4}$, \\ Nan Liu ${ }^{4}$ and Hai Ren ${ }^{4 *}$
}

'Guangdong Open Laboratory of Geospatial Information Technology and Application, Guangdong Academy of Sciences, Guangzhou Institute of Geography, Guangzhou, China, ${ }^{2}$ Guangdong Provincial Key Laboratory of Forest Silviculture, Protection and Utilization, Guangdong Academy of Forestry, Guangzhou, China, ${ }^{3}$ Departamento de Botânica, Laboratório de Sistemática Vegetal, Instituto de Ciências Biológicas, Universidade Federal de Minas Gerais, Belo Horizonte, Brazil, ${ }^{4}$ Key Laboratory of Vegetation Restoration and Management of Degraded Ecosystems, South China Botanical Garden, Chinese Academy of Sciences, Guangzhou, China

\section{OPEN ACCESS}

Edited by:

Boris Rewald,

University of Natural Resources and

Life Sciences Vienna, Austria

Reviewed by:

Klaus Mehltreter,

Instituto de Ecología (INECOL), Mexico Michael Kessler

University of Zurich, Switzerland

*Correspondence:

Hai Ren

renhai@scib.ac.cn

Specialty section:

This article was submitted to

Functional Plant Ecology,

a section of the journal

Frontiers in Plant Science

Received: 09 July 2020

Accepted: 14 December 2020

Published: 13 January 2021

Citation:

Yang $L$, Huang Y, Lima LV, Sun Z,

Liu M, Wang J, Liu N and

Ren H (2021) Rethinking the

Ecosystem Functions of

Dicranopteris, a Widespread Genus

of Ferns.

Front. Plant Sci. 11:581513.

doi: 10.3389/fp/s.2020.581513
Dicranopteris is an ancient and widespread genus of ferns in pantropical regions. Some species of the genus can form dense thickets, and dominate the understory, which are common and key species in tropical and subtropical ecosystems. However, they were mostly cut or burned in forest management because of forming dense thickets which were considered to interfere with forest regeneration and succession. In the current review, we argue that the Dicranopteris species which are able to rapidly colonize barren areas may contribute to ecosystem recovery, resistance to environmental stress, and succession control. Rapid colonization involves prolific spore production, rapid clonal growth, the generation of high surface cover, and the ability to fill gaps; stress resistance includes resistance to abiotic stress, and the ability to reduce soil erosion from rainfall, alien species invasion, and soil contamination and toxicity; and succession facilitation consists of carbon and nutrient sequestration in soil, moderation of the microclimate, alteration of the soil microbial and faunal communities, and determination of which plant species to be established in the next successional stage. All of these ecosystem functions may be beneficial to ecosystem resilience. We expect that the distribution of Dicranopteris will expand in response to global warming, changes in precipitation patterns, increases in soil pollution, deforestation, and land degradation. We recommend that Dicranopteris, as a pioneer fern and a valuable component of tropical and subtropical ecosystems, needs more attention in future research and better management practices to promote forest regeneration and succession.

Keywords: Dicranopteris, ecosystem function, facilitation and competition, ecosystem resilience, succession facilitation, tropical forest

\section{INTRODUCTION}

Dicranopteris (forked fern) is a genus of about 12 extant, common pioneer species in pantropical regions (Pteridophyte Phylogeny Group, 2016), which is an ancient fern genus of the family Gleicheniaceae (Filicopsida). The origin of ferns is estimated to have occurred in the mid-Silurian (Testo and Sundue, 2016). It is estimated that Dicranopteris diverged from Gleichenella about 38 m.a., which places the rise of the genus in late Eocene (Liu et al., 2020). Among them, six Dicranopteris species can form dense thicket (Figure 1). 
Some Dicranopteris species are concentrated in Asia, such as Dicranopteris dichotoma in East Asia and Dicranopteris curranii in Southeast Asia. In the neotropical region, there are four species of Dicranopteris of which Dicranopteris flexuosa is the most common and widespread species. The other Dicranopteris species include Dicranopteris seminuda restricted to the Andes, Dicranopteris nervosa with populations in south and southeastern Brazil, Bolivia, and Peru, and Dicranopteris rufinervis endemic to Brazil (Lima and Salino, 2018).

Plants of Dicranopteris consist of fronds, aerial stems, rhizomes, and adventitious roots. Pinnae and aerial stems constitute the aboveground part, whereas the underground stems and adventitious roots constitute the underground part (Liu et al., 2008). Dicranopteris are scrambling plants with pseudodichotomously branched fronds, which can reach $45-200 \mathrm{~cm}$ in height (Zhang et al., 2010). The rhizome may grow buried in soil or close to surface. The rhizome is long-creeping, and the fronds may reach up to $2 \mathrm{~m}$ in length. In most cases, the fronds are pendant and the new fronds rest on the older ones, usually forming dense thickets (Andersen and Øllgaard, 1996; Mickel and Smith, 2004; Lima and Salino, 2018). The aboveground part can intercept and retain winddispersed seeds by reducing wind velocity and increase the coverage and retention of animal-dispersed seeds as well. The underground part of the rhizomes and adventitious roots are arranged in a crisscrossed pattern, which resembles a fine sieve that is filled with litter and soil. Tropical and subtropical regions have received considerable attention from ecologists because they have huge carbon (C) pools (Phillips et al., 1998; Mitchard, 2018) and high biodiversity (Molino and Sabatier, 2001; Volkov et al., 2005), as well as provide many ecosystem services (Hietz et al., 2011; Hirota et al., 2011). Previous studies of ecosystem functions in tropical and subtropical regions primarily focus on dominant and overstory species of gymnosperms and angiosperms rather than on pioneer fern species (Molino and Sabatier, 2001; Volkov et al., 2005). Although such pioneer fern species dominate in the early stages of forest succession (Walker, 1994; Walker and Boneta, 1995; Walker and Sharpe, 2010), their ecological functions in general and contributions to succession in particular have rarely been studied due to their low biomass and diversity ( $\mathrm{Wu}$ et al., 2011; Yang et al., 2014). Dicranopteris species have often been considered as competitive obstacles to forest regeneration and succession because of thickets that they form (Huan et al., 1984; Cohen et al., 1995; Slocum et al., 2004, 2006; Pang et al., 2018). In contrast, after reviewing recent studies, we found that Dicranopteris species may have important ecosystem functions. Especially Walker and Sharpe (2010) already covered both effects of Gleicheniaceae, inhibition and facilitation. Finally, we performed a comparison of the ecosystem functions between Dicranopteris and another widespread and often invasive genus, Pteridium, which has been studied far better than the former genus. After describing how Dicranopteris species may help support succession in pantropical ecosystems, we suggest future research directions in the context of global environmental change.

\section{PAST UNDERSTANDING OF THE ECOSYSTEM FUNCTIONS OF DICRANOPTERIS}

Dicranopteris species generally form a single-species dominant community due to their superior propagation ability

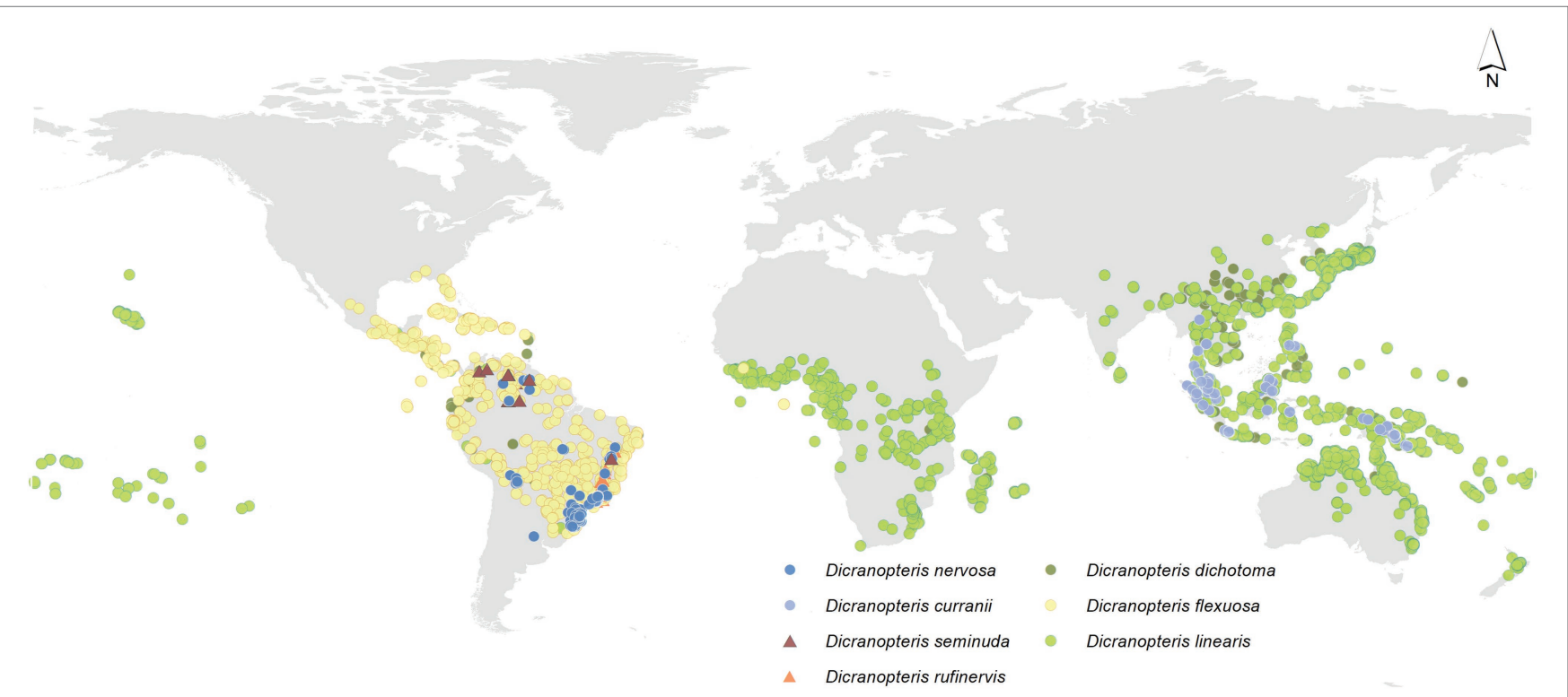

FIGURE 1 | Global distribution of Dicranopteris species, including Dicranopteris dichotoma (deep green dots), Dicranopteris curranii (shallow blue dots), Dicranopteris flexuosa (yellow dots), Dicranopteris seminuda (brown triangles), Dicranopteris nervosa (navy blue dots), Dicranopteris rufinervis (orange triangles), and Dicranopteris linearis (green dots). The distribution information was mainly obtained from Global Biodiversity Information Facility (gbif.org), sampling by Long Yang in East Asia and Lucas Vieira Lima in the neotropics. 
(Lin, 2004) and allelopathic effects (Yuan and Li, 2007). First, they can propagate through sexual reproduction (spores) and vegetative reproduction (clones) to form single-species dominant community. Vegetative propagation is more important for fast growth and occupying ecological space. Second, the allelopathic effect leads to difficult recruitment of other species. During the early successional stage of tropical and subtropical plant communities, Dicranopteris species are common and keystone taxa. However, the role of Dicranopteris is controversial in tropical ecology. Dicranopteris species have often been considered as obstacles that interfere with forest succession because they form thickets which compete with trees for soil water, soil nutrients, and solar radiation. This assessment has been applied to D. dichotoma in South China (Huan et al., 1984; Pang et al., 2018) and Dicranopteris linearis in Sri Lanka (Cohen et al., 1995) and Hawaii (Russell, 1996). In the short run, Dicranopteris species can inhibit seedling regeneration of late-successional species. However, in the long term, ecosystems are able to undergo succession (Chua et al., 2013).

In degraded land of South China, the aboveground biomass and rhizomes of $D$. linearis have often been burnt to slow down their growth and regeneration, the degraded land was turned over so that the rhizomes and roots were exposed to the sun, and then legumes were planted to replace the Dicranopteris (Huan et al., 1984). In montane forest in the Dominican Republic, woody species of different successional stages were planted to increase plant diversity after clearing the Dicranopteris thickets (Slocum et al., 2006). Bracken fern (Pteridium) has similar situation with Dicranopteris. Pteridium was described as an aggressive pioneer plant species worldwide (Le Duc et al., 2007). Pteridium can also form dense thickets for stronger allelopathic chemicals and rapid clone propagation. Thus, many control measures were carried out to restore the primary vegetation. Compared with the treatment of cutting once per year or asulam spraying, cutting twice per year can effectively control the expansion of invasive weed Pteridium in Great Britain (Cox et al., 2007; Le Duc et al., 2007; Stewart et al., 2008; Milligan et al., 2018).

Dicranopteris species share the following characteristics at the local scale: dense growth, the ability to form near monocultures, and a deep root blanket. All Dicranopteris species require strong sunlight, and commonly grow in pioneer communities, on barren slopes, or in sparse forests (Zhu et al., 2016). As the most common pioneer species in tropical and subtropical regions, Dicranopteris species play an essential role in microclimate formation, nutrient accumulation, nutrient cycling, and energy flux (Duan et al., 2010). Compared to ferns that grow in more shaded environments, Dicranopteris species have higher nutrient-use efficiencies and shorter leaf life spans and payback times (Zhu et al., 2016). However, the ecosystem functions of Dicranopteris have not been well acknowledged in previous studies. In the following sections, we summarize the ecosystem functions of Dicranopteris and provide an integrated framework to identify their ecological roles in the tropics and subtropics.

\section{ECOSYSTEM FUNCTIONS OF DICRANOPTERIS}

\section{Colonization of the Habitat by Dicranopteris}

After a rainfall event, Dicranopteris can recolonize almost the entire surface area of a degraded and thus patchily colonizes a habitat. Dicranopteris species can reproduce via spores and clonal growth (Lin, 2004). The number of $D$. dichotoma spores in the top $0-5 \mathrm{~cm}$ of soil can be as high as $200,000 \mathrm{~cm}^{-3}$, and these spores can germinate in warm and rainy season in subtropical China. For D. linearis, sexual reproduction via the germination of dispersed spores also appears to be important during the earlier stage of colonization; the main evidence is that at least three-quarters of the genotypes are produced via outcrossing (Russell, 1996). Although spore propagation is critical in primary succession, clonal propagation is a more important means of vegetative growth and allows the plants to cover the entire surface of the landscape (Figure 2). The elements nitrogen $(\mathrm{N})$, phosphorus $(\mathrm{P})$, potassium $(\mathrm{K})$, and aluminum (Al) accumulate in Dicranopteris rhizomes, which benefits from clonal propagation (Chen and Zhong, 1991). The strong vegetative growth ability of Dicranopteris species allows them to quickly cover degraded land and form a community of a single dominant species. As indicated by low genetic diversity, clonal propagation and growth are the primary means by which $D$. linearis covers degraded landscapes (Russell et al., 1999). Dicranopteris species also have a high colonization ability as a result of their pulsed growth. With sufficient precipitation and soil nutrients, Dicranopteris can grow quickly. However, the species grow slowly in dry season and in barren soils, which suggests that this pulsed growth probably improves resource-use efficiency (Lin, 2004). Moreover, the near modular

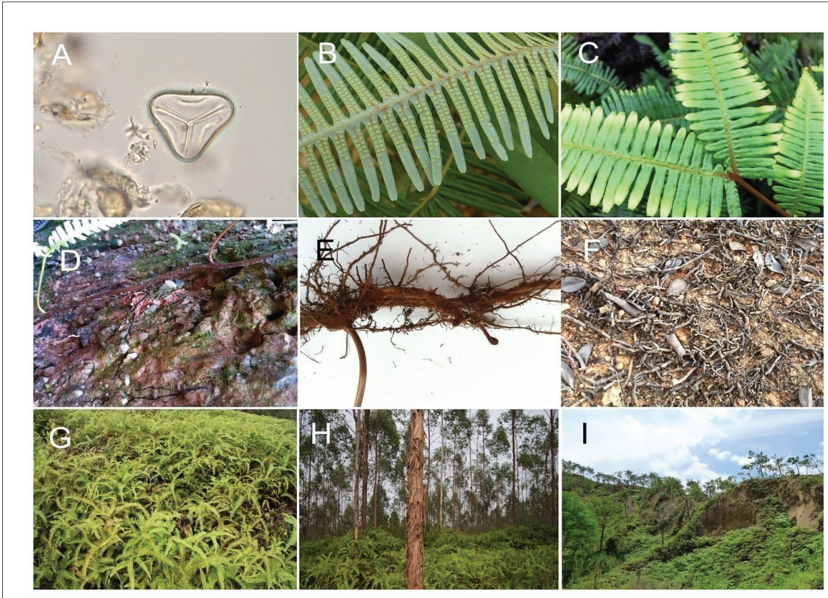

FIGURE 2 | Individuals and communities of Dicranopteris. (A) Spores $\times 400$ (B) Leaf blade and abaxial sporangia. (C) Leaf traits. (D) Underground stems (rhizomes). (E) Underground stems and roots. (F) Post-fire underground stems. (G) A Dicranopteris community on degraded land. (H) Understory Dicranopteris layer. (I) Dicranopteris cover in an area with soil erosion. Photographs were taken in Eucalyptus forests, Pinus forests, or degraded shrubland in subtropical China. 
growth of the fronds provided by the dormant bud could be helpful in this process.

\section{Resistance to Environmental Stress and Changes}

\section{Resistance to Environmental Stress}

Dicranopteris species, in contrast to most plants, can endure strong solar radiation, high temperatures, acidity, infertile soil, and drought, which can also thrive in humid environments (Russell, 1996). The desiccation tolerance of D. linearis is attributed to its high antioxidant capacity (Kavitha and Murugan, 2016). In addition, the maximum temperatures are substantially lower in a Dicranopteris cover than in surrounding areas (Negishi et al., 2006). Because of their very high $\mathrm{N}$ - and P-use efficiencies, Dicranopteris species can occupy the surfaces of infertile soil (Russell, 1996). During primary succession, Dicranopteris communities alter the soil and microenvironment of the area. Dicranopteris species are more tolerant than other species to drought stress because of their higher water-use efficiency. In Pinus forests, the water-use efficiency of Dicranopteris reached $8 \mu \mathrm{mol} \cdot \mathrm{CO}_{2} \cdot \mathrm{mmol}^{-1} \mathrm{H}_{2} \mathrm{O}$, which was higher than that of most other understory species (Zhang et al., 2010).

\section{Resistance to Soil Erosion Caused by Rainfall}

Dicranopteris communities are beneficial to ecosystems by conserving water and soil in the following ways (Chen et al., 2016; Chen and Chen, 2018; Jiang et al., 2019). First, the leaves of a Dicranopteris can reduce splash erosion. Second, the rhizomes and adventitious roots are arranged in a crisscross pattern, which reduces linear erosion and sheet erosion from rainfall runoff. Third, the roots of Dicranopteris are short and highly branched and tend to hold soil particles and aggregates in place. In the absence of the aboveground parts of Dicranopteris, the nonflammable rhizomes and adventitious roots can firmly fix the surface soil following fire events. For instance, D. linearis (Zheng et al., 2008), D. curranii (Negishi et al., 2006), and D. dichotoma (Yue et al., 2014) reduced soil erosion by reducing runoff, mitigating splash and hydraulic surface erosion processes, and trapping sediment.

\section{Resistance to Alien Species Invasion}

Several growth and physiochemical traits are shared by Dicranopteris and invasive species, which include a preference for strong solar radiation, rapid growth, a strong reproductive ability, and allelopathic effects. As a consequence, Dicranopteris species can effectively compete with invasive species. More specifically, Dicranopteris species exhibit dense growth and always form a community with a single dominant species. The dense canopy and understory clonal stems occupy a large area and shade the microenvironment, which can limit the growth of other species. Because of their rapid clonal growth and spores reproduction, Dicranopteris species can also inhibit the establishment of alien species via nutrient limitation and the impediment of recruitment (Russell et al., 1999). In a Hawaiian rainforest, for example, alien species were unable to establish in Dicranopteris-colonized areas but were able to establish after Dicranopteris removal (Russell et al., 1998). Dicranopteris species also have strong allelopathic effects, which may inhibit the survival and growth of alien species (Zhang et al., 2004). In South China, for example, an aqueous extract of Dicranopteris was found to inhibit the germination and seedling growth of Wedelia trilobata and Mikania micrantha, two invasive species in this region (Zhao et al., 2007; Wu, 2008). Researchers have even suggested that Dicranopteris allelochemicals might be used to develop bioherbicides and potential insecticide to control alien species invasions (Zhao et al., 2007). Although the role of allelochemicals of Dicranopteris are considered important, their underlying mechanisms are still unclear. With regards to the presence of phytoecdysteroids, studies were carried out in some species of Gleicheniaceae (Hikino and Hikino, 1970; Russell and Fenemore, 1970). The major secondary compounds as allelochemical in bracken fern Pteridium included proanthocyanidin selligueain A (de Jesus Jatoba et al., 2016), phenolics, and condensed tannins (Alonso-Amelot et al., 2004).

\section{Mitigation of Soil Contamination and Toxicity}

Ferns are always considered as heavy metal accumulators, and some are found to be hyperaccumulators. For example, it was found that bracken fern (Pteridium aquilinum) can accumulate chromium $(\mathrm{Cr})$ and nickel $(\mathrm{Ni})$ in rhizome and fronds (Kubicka et al., 2015), and Chinese brake fern (Pteris vittata) is a hyperaccumulator of arsenic (Chen et al., 2002). Dicranopteris always grows in acidic soils with high contents of $\mathrm{Al}$ and manganese $(\mathrm{Mg})$. $\mathrm{Al}$ and $\mathrm{P}$ combine to form aluminum phosphate, which is thought to reduce P availability. Dicranopteris can absorb $\mathrm{Al}$, which reduces $\mathrm{Al}$ toxicity and increases P-use efficiency (Russell et al., 1998). Dicranopteris can also remove soil pollutants, such as heavy metal elements, rare earth elements, and radioactive elements. Many studies have shown that Dicranopteris has a strong ability to accumulate lead ( $\mathrm{Pb}$; Bi et al., 2006). The concentration of $\mathrm{Pb}$ in Dicranopteris was much higher in plants growing in lead-zinc mine wasteland $(59.5 \mathrm{mg} / \mathrm{kg})$ than in a non-polluted site $(5 \mathrm{mg} / \mathrm{kg}$; Bi et al., 2006) and even reached $556 \mathrm{mg} / \mathrm{kg}$ in the tungsten mine area of South China (Liu et al., 2008). Dicranopteris was also found to absorb zinc (Zn), tungsten $(\mathrm{W})$, manganese $(\mathrm{Mn})$, and cadmium $(\mathrm{Cd})$ in the mining area of South China (Liu et al., 2008; Yang et al., 2012) and to assimilate rare earth elements, such as lanthanum (La), cerium $(\mathrm{Ce})$, praseodymium $(\mathrm{Pr})$, and neodymium $(\mathrm{Nd}$; Wang et al., 203). D. linearis can even absorb radioactive elements, such as radium (Ra) and thorium (Th; Chao and Chuang, 2011; Song et al., 2014). Dicranopteris can be used to mitigate soil contamination and toxicity due to its high biomass accumulation, rapid growth, strong adaptability, and high bioconcentration ability (1.88-2.74; Song et al., 2014; Table 1).

\section{RECOGNITION OF THE ECOSYSTEM FUNCTIONS OF DICRANOPTERIS: ECOSYSTEM SUSTAINABILITY}

\section{Carbon and Soil Nutrient Sequestration}

Dicranopteris can survive for decades (Lin, 2004). The death of a large Dicranopteris clone provides a pulse of organic 
TABLE 1 | Soil contaminated types and elements accumulated by Dicranopteris species.

\begin{tabular}{|c|c|c|c|}
\hline $\begin{array}{l}\text { Soil contaminated } \\
\text { types }\end{array}$ & Elements & $\begin{array}{l}\text { Dicranopteris } \\
\text { species }\end{array}$ & References \\
\hline Al toxicity & $\mathrm{Al}$ & $\begin{array}{l}\text { Dicranopteris } \\
\text { linearis }\end{array}$ & Russell et al., 1998 \\
\hline \multirow[t]{6}{*}{ Heavy metal } & $\mathrm{Zn}$ & $\begin{array}{l}\text { Dicranopteris } \\
\text { dichotoma }\end{array}$ & $\begin{array}{l}\text { Liu et al., 2008; Yang et al., } \\
2012\end{array}$ \\
\hline & $\mathrm{Cd}$ & D. dichotoma & $\begin{array}{l}\text { Liu et al., 2008; Yang et al., } \\
2012\end{array}$ \\
\hline & Mo & D. dichotoma & Liu et al., 2008 \\
\hline & $\mathrm{Cu}$ & D. dichotoma & Liu et al., 2008 \\
\hline & $\mathrm{Pb}$ & D. dichotoma & $\begin{array}{l}\text { Bi et al., 2006; Chen et al., } \\
\text { 2011; Yang et al., } 2012\end{array}$ \\
\hline & W & D. dichotoma & Liu et al., 2008 \\
\hline \multirow[t]{2}{*}{ Semimetal } & As & D. dichotoma & Wei et al., 2007 \\
\hline & $\mathrm{Ba}$ & D. dichotoma & Koyama et al., 1987 \\
\hline \multirow[t]{4}{*}{ Rare earth } & $\mathrm{La}$ & D. dichotoma & Wang et al., 2003 \\
\hline & $\mathrm{Ce}$ & D. dichotoma & Wang et al., 2003 \\
\hline & $\operatorname{Pr}$ & D. dichotoma & Wang et al., 2003 \\
\hline & $\mathrm{Nd}$ & D. dichotoma & Wang et al., 2003 \\
\hline \multirow[t]{2}{*}{ Radioactivity } & $\mathrm{Ra}$ & D. linearis & $\begin{array}{l}\text { Chao et al., 2011; Song } \\
\text { et al., } 2014\end{array}$ \\
\hline & Th & D. linearis & $\begin{array}{l}\text { Chao et al., 2011; Song } \\
\text { et al., } 2014\end{array}$ \\
\hline
\end{tabular}

matter to the detrital pool and alters forest floor microenvironments, thus influencing species-specific colonization dynamics, organic matter, and nutrient cycling processes (Russell et al., 1999). In addition, Dicranopteris communities can reduce nutrient loss through runoff and leaching (Zheng et al., 2008). Dicranopteris communities have also been found to accelerate litter decomposition (Wu et al., 2011; Liu et al., 2012; Zhao et al., 2012; Yang et al., 2014). In open forests, forest litterfall can be intercepted by Dicranopteris communities before it reaches the ground; the litter decomposition rate was lower in the top part than in the bottom part of the communities, and the overall decomposition rate was faster in the communities than outside of the communities (Yang et al., 2014). Functioning as catalyzers, Dicranopteris communities increase carbon cycling and soil carbon accumulation in the whole ecosystem via abovegroundunderground carbon flow (Guan, 2001; Wan et al., 2014). Soil organic carbon content was found to significantly increase in association with Dicranopteris communities, and dissolved organic carbon (DOC) and light fraction organic carbon (LFOC) were two and five times higher, respectively, in areas with than without Dicranopteris communities (Jiang, 2013). Soil organic carbon and total nitrogen content with Dicranopteris (49.01 and $2.37 \mathrm{t} \mathrm{ha}^{-1}$ ) was obviously higher than that without Dicranopteris (28.11 and $1.65 \mathrm{t} \mathrm{ha}^{-1}$ ) in 30-year Pinus massoniana forest (Jiang, 2013). It was also showed that soil nitrate increased after bracken fern $P$. aquilinum invasion (DeLuca et al., 2013; Bardon et al., 2018). In addition, decreases in the litter decomposition rates led to reductions in nutrient availability in a series of Dicranopteris removal experiments (Negishi et al., 2006; Zhao et al., 2012). These results indicate that Dicranopteris communities increase carbon and soil nutrient sequestration.

\section{Causes of Regeneration and the Control of Ecological Thresholds}

For succession to proceed or for restoration to be successful, certain abiotic and biotic thresholds must be surpassed (Ren et al., 2006). As indicated in Figure 3, Dicranopteris species enable succession to proceed via abiotic effects (by reducing solar radiation, wind speed, and high temperatures, and by increasing humidity and soil moisture and nutrient content) and via biotic effects (by altering the soil microbial and faunal community, by increasing soil seed bank diversity, and by the screening of seedlings; Ren et al., 2006). Dicranopteris was considered as an ecological filter (Zhang et al., 2010). Dicranopteris species improve soil structure and increase soil nutrient content by reducing water and soil loss and by fixing carbon and nitrogen (Guan, 2001; Xie et al., 2006; Chen et al., 2014). Dicranopteris species increase the diversity in the soil seed bank by intercepting the "seed rain" compared with bare ground. This "root sieve" is more than $10 \mathrm{~cm}$ deep and insulates the aboveground part of Dicranopteris and the soil layer (Zhang et al., 2010). The seeds retained by the aboveground part are intercepted by the underground part. These seeds eventually settle through various layers, which represent a physical, chemical, and biological screening. Seeds that pass through these screens may germinate, and the resulting seedlings may infiltrate the Dicranopteris communities. These species can shape the soil seed and seedling bank at the later stages of ecological succession. Most species cannot recruit in Dicranopteris communities due to the allelopathic effects of Dicranopteris species (Ismail and Chong, 2007). Dicranopteris may have allelopathic effect on two invasive species, Bidens pilosa and Eupatorium catarium in South China, and the allelochemical, such as 2,3-Butanediol and 1,2,3-propanetriyl ester, which may play an important role in inhibitory effects of invasive species (Juma et al., 2019). This phenomenon of ecological filter was found in other ferns. Bracken fern Pteridium were also regarded as ecological filters worldwide (Senyanzobe et al., 2020). The seedling establishment of rainforest species in Brazil, Scots pine and Norway spruce in Sweden, and tropical species in Africa can be significantly interfered by Pteridium (Dolling, 1996; Silva Matos and Belinato, 2010; Ssali et al., 2019). Proanthocyanidin selligueain A is the major secondary compound in the green fronds and litter of Pteridium (de Jesus Jatoba et al., 2016).

\section{Successional Facilitation}

Successional trajectories are determined by stable environmental factors, such as air temperature, precipitation, geological conditions, and soil type, and even by the presence of stable keystone species. Under global climate change, these stable factors may change to some degree, thereby altering interspecific associations and successional trajectories. On sunny slopes in South China, D. dichotoma biomass can reach $11,320 \mathrm{~kg} / \mathrm{ha}$ (Yue, 2009). As previously noted, Dicranopteris grows best in environments with high light penetration, such as on bare land or in open forests, and Dicranopteris thickets are known to persist for decades once established (Russell, 1996). Shade intolerance is the Achilles' Heel of Dicranopteris. 


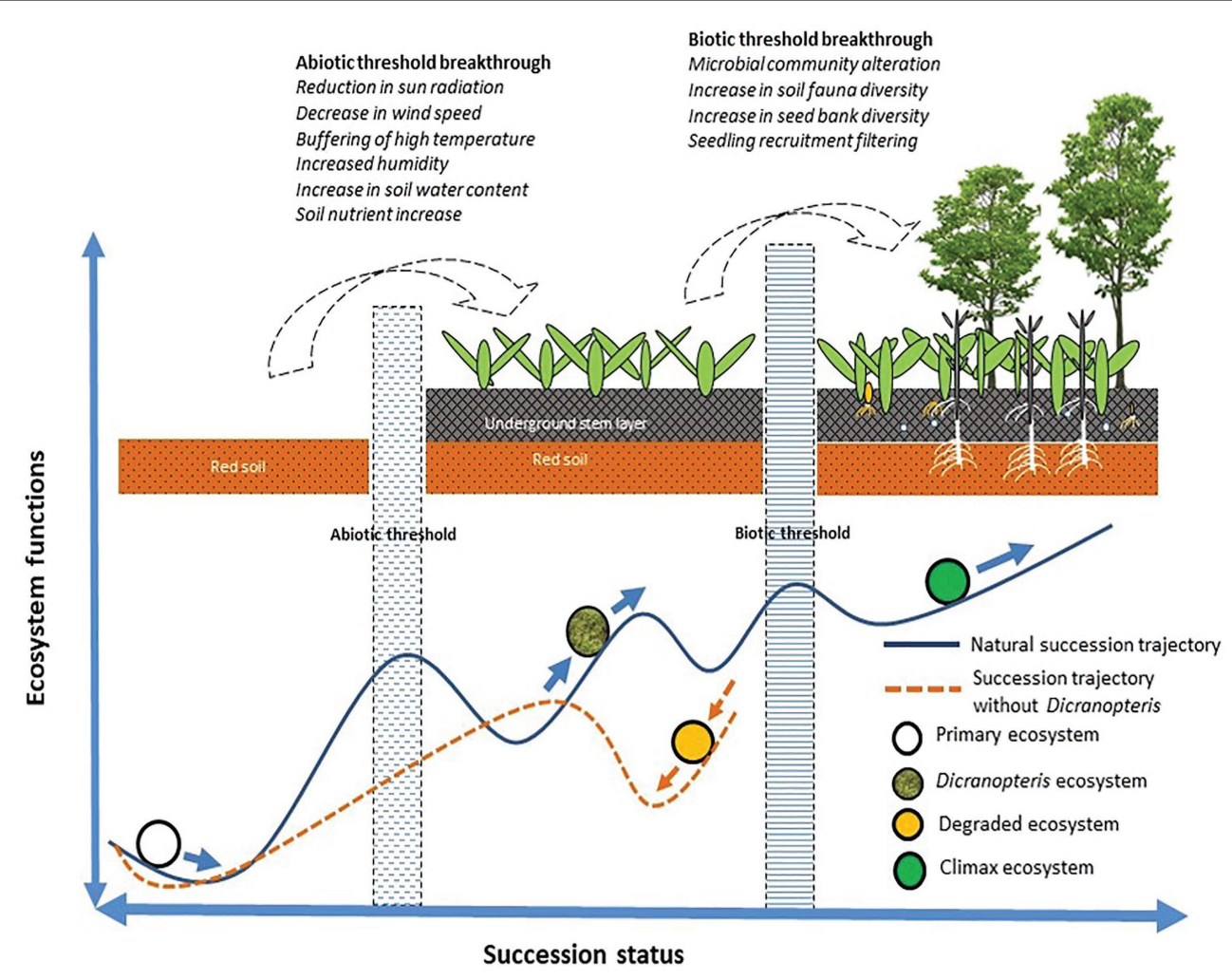

FIGURE 3 | A model of how Dicranopteris communities facilitate to overcome the abiotic and biotic thresholds of succession (based on Sun et al., 2013).

Dicranopteris species can protect the successional process by relinquishing their dominance as the canopies of the dominant species in later successional stages increasingly reduce light penetration. The successional trajectory always progresses from ferns to shrubs and then to broad-leaved forests in the tropics and subtropics. Dicranopteris species are always dominant during the earlier-successional stage. An interesting study in subtropical China showed that the shrub Rhodomyrtus tomentosa was the first plant to colonize a burned, degraded area (Yang et al., 2010); when all of the shrubs were killed by a parasitic vine (Cassytha filiformis), the bare area was invaded and covered by Dicranopteris. Ban et al. (2008) concluded that the entire successional process began with the presence of Dicranopteris.

\section{FUTURE RESEARCH DIRECTIONS REGARDING THE ECOSYSTEM FUNCTIONS OF DICRANOPTERIS}

\section{Long-Term and Global-Scale Research Framework/Agenda}

Long-term research can increase our understanding of changes in ecosystem structure and function (Kuebbing et al., 2018). To date, long-term studies of Dicranopteris are rare. Although studies lasting 1-2 years have been conducted with Dicranopteris (Wu et al., 2011; Zhao et al., 2012; Yang et al., 2014), such short-term investigations, especially when involving Dicranopteris removal, cannot fully explain the ecosystem functions of these species. For example, successional trajectory protection may be the key ecosystem function of Dicranopteris, but this protection becomes manifested after more than 1 or 2 years. Another example considers the role of Dicranopteris in ecological filtering. This key ecosystem function is a long-term ecological process involving the effects of communities on seed retention, seed germination, seedling screening, and seedling establishment. Although published reports support the model in Figure 3 and the ecological functions listed in Figure 4, long-term research is greatly needed to clarify the ecological functions of Dicranopteris species and their effects on forest succession in tropical and subtropical regions.

Dicranopteris can be considered as a global pioneer species in the tropics and subtropics. However, almost all studies on Dicranopteris have been conducted at the local scale, and global-scale research on Dicranopteris is still lacking. A global-scale research network for the genus would be useful. Current global-scale research networks concerning various ecological and evolutionary topics include the International Long Term Ecological Research Network (ILTER), the Global Biodiversity Information Facility (GBIF), the Center for Tropical Forest Science - Forest Global Earth Observatory (CTFS-Forest GEO), and the International Canopy Network (ICN). A global research network would be useful for answering a variety of fundamental questions. For example, Why are 


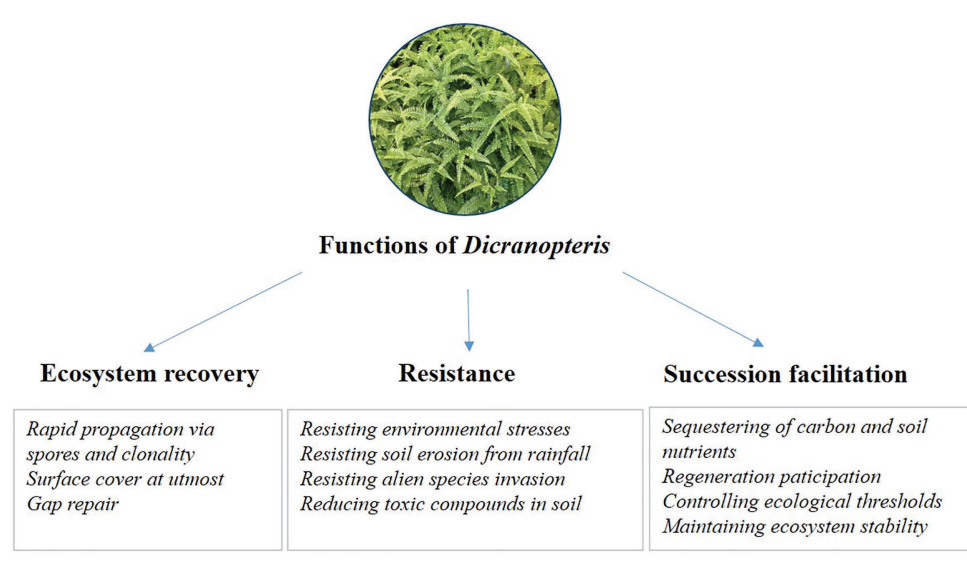

FIGURE 4 | The proposed ecological functions of Dicranopteris, including ecosystem recovery, resistance, and succession facilitation.

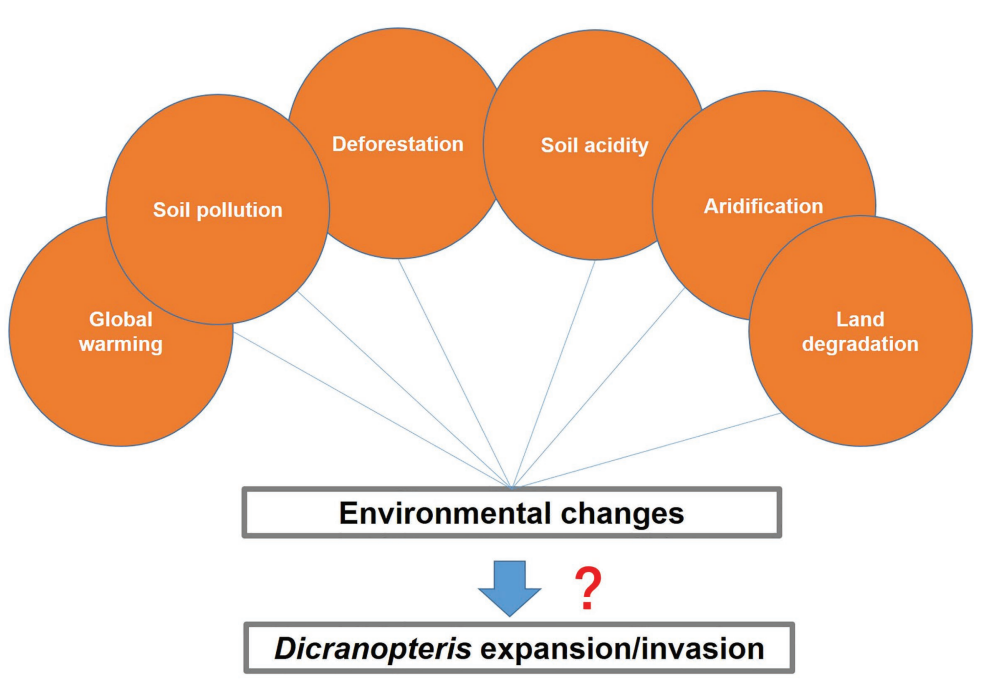

FIGURE 5 | Environmental changes that may lead to Dicranopteris expansion or invasion.

the number of Dicranopteris species so small? Is that attributed to the low genetic diversity in all Dicranopteris species? Will the distribution of Dicranopteris expand under the scenario of changing global environments?

\section{Fusion of Ancient and Modern Data}

Information on species co-occurring with Dicranopteris spores can, therefore, be used as an indicator of how the ecological role of the genus may have changed under different climates. For example, the combination Dicranopteris-Cibotium-Castanopsis in the stratigraphic record indicates a humid environment with tropical and subtropical ferns, while the combination Pinus-Castanopsis-Quercus-Gramineae-Dicranopteris indicates tropical and subtropical grasslands (Peng et al., 2015). The current presence of Dicranopteris, in contrast, indicates early stages of succession in tropical and subtropical forests. Dicranopteris spores are consistently found in various strata, suggesting the important role of these species in the past (Sun et al., 2016). Big data regarding Dicranopteris from worldwide strata should be reanalyzed, and ancient and modern data should be combined to determine how the ecological roles of Dicranopteris species may change in the future.

\section{Predicted Expansion and Functions of Dicranopteris in a Changing Environment}

The Earth's environment is changing via global warming, land degradation, deforestation, aridification, nitrogen deposition, soil acidification, soil pollution, etc. Further research is needed to answer the following questions relevant to global change: Can stable species, such as Dicranopteris, act as refuges that facilitate the establishment of unstable species under the scenario of global change? What are the mechanisms of Dicranopteris expansion? Can Dicranopteris adapt to the changing global environments? Few studies referred to the 
impact of global change to Dicranopteris in the past. Another bracken fern Pteridium species (such as Pteridium aquilinum) that is similar with Dicranopteris have been regarded as aggressive and invasive pioneer plant species in a changing world (Gaudio et al., 2011). Although warming and elevated $\mathrm{CO}_{2}$ did not change the growth of Pteridium (Whitehead et al., 1997; Caporn et al., 1999), nitrogen deposition and drought frequency may affect it (Gordon et al., 1999). Temperatures for Dicranopteris are generally more suitable in tropical than in temperate regions. With global warming, the climatic zone of the tropics is expected to move to highlatitude areas, which may cause Dicranopteris to evolve temperature adaptability. Additionally, deforestation and land degradation frequently occur in the tropics and subtropics, and thereby increase exposures to sunlight and the production of xeric environments. These conditions are consistent with the sun-loving and drought-tolerant traits of Dicranopteris. The establishment of most plant species except for Dicranopteris species is prevented in soils that have experienced high levels of nitrogen deposition, acid deposition, and heavy metal contamination. Therefore, the expansion of Dicranopteris, similar to that of bamboo, can be predicted to occur in the changing environments of the future. Future research is needed to test these hypotheses and to fill the gaps (Figure 5).

\section{REFERENCES}

Alonso-Amelot, M. E., Oliveros, A., and Calcagno-Pisarelli, M. P. (2004). Phenolics and condensed tannins in relation to altitude in neotropical Pteridium spp. A field study in the Venezuelan Andes. Biochem. Syst. Ecol. 32, 969-998. doi: 10.1016/j.bse.2004.03.005

Andersen, E. Ø., and Øllgaard, B. (1996). A note on some morphological terms of the leaf in the Gleicheniaceae. Am. Fern J. 86, 52-57. doi: $10.2307 / 1547368$

Ban, J. W., Yin, Z. Y., Zhang, Q. M., and Wei, M. S. (2008). The changes of ecological characteristics of degraded hilly grassland during the transformation from herb dominance to shrub dominance in Heshan, Guangdong. Trop. Geogr. 28, 129-133.

Bardon, C., Misery, B., Piola, F., Poly, F., and Roux, X. L. (2018). Control of soil $\mathrm{N}$ cycle processes by Pteridium aquilinum and Erica cinerea in heathlands along a pH gradient. Ecosphere 9:e02426. doi: 10.1002/ecs2.2426

Bi, D., Wu, L. H., Luo, Y. M., Zhou, S. B., Tan, C. Y., Yin, X. B., et al. (2006). Dominant plants and their heavy metal contents in six abandoned lead-zinc mine areas in Zhejiang Province. Soil 38, 591-597.

Caporn, S. J. M., Brooks, A. L., Press, M. C., and Lee, J. A. (1999). Effects of long-term exposure to elevated $\mathrm{CO}_{2}$ and increased nutrient supply on bracken (Pteridium aquilinum). Funct. Ecol. 13(Suppl. 1), 107-115. doi: 10.1046/j.1365-2435.1999.00013.x

Chao, J. H., and Chuang, C. Y. (2011). Accumulation of radium in relation to some chemical analogues in Dicranopteris linearis. Appl. Radiat. Isot. 69, 261-267. doi: 10.1016/j.apradiso.2010.08.012

Chen, Z., and Chen, Z. (2018). Effects of ecological restoration measures on the distribution of Dicranopteris dichotoma at the microscale in the red soil hilly region of China. PLoS One 13:e0204743. doi: 10.1371/journal. pone. 0204743

Chen, S. -X., Chen, J. -D., Xie, L., Liao, J. -W., Zhang, J. -C., and Yang, Q. -L. (2011). Heavy metal accumulation characteristics of plants in Dabaoshan Mine in Guangdong Province. J. Soil Water Conserv. 25, 216-220.

Chen, Z., Chen, Z., Yan, X., and Bai, L. (2016). Stoichiometric mechanisms of Dicranopteris dichotoma growth and resistance to nutrient imitation in the Zhuxi watershed in the red soil hilly region of China. Plant Soil 398, 367-379. doi: 10.1007/s11104-015-2670-7

\section{AUTHOR CONTRIBUTIONS}

LY, YH, ZS, and HR conceived the study. LY, LL, ML, ZS, $\mathrm{YH}, \mathrm{JW}$, and NL analyzed the data and contributed reagents, materials, and analysis tools. LY, YH, LL, ZS, JW, NL, and HR wrote the paper. All authors contributed to the article and approved the submitted version.

\section{FUNDING}

This study was funded by the National Natural Science Foundation of China (no. 31770473 and 31000212), Guangdong Science and Technology Project (2018B030324002), and GDAS' Special Project of Science and Technology Development (2017GDASCX0101, 2019GDASYL-0104002, and 2020GDASYL-0104002).

\section{ACKNOWLEDGMENTS}

We thank our colleagues at the Heshan National Field Research Station of Forest Ecosystems, especially Shenglei Fu, Weijun Shen, Guoyi Zhou, and Zhian Li, for helpful suggestions. We also thank two reviewers for their constructive suggestions, and Zhihui Wang and Bruce Jaffee for polishing the English.

Chen, T., Jiang, J., Yang, Y. H., Lv, M. K., Xu, C., Fu, L. C., et al. (2014) Effects of Dicranopteris dichotoma on soil organic carbon and soil total nitrogen during revegetation process in red soil erosion area. J. Nanchang Inst. Technol. 33, 23-27.

Chen, T. B., Wei, C. Y., and Huang, Z. C. (2002). Arsenic hyperaccumulator Pteris vittata L. and its arsenic accumulation. Chin. Sci. Bull. 47, 902-905. doi: $10.1360 / 02$ tb9202

Chen, J., and Zhong, Z. C. (1991). Characteristics of nutrient elements cycling in fern community. Acta Ecol. Sin. 11, 299-306.

Chua, S. C., Ramage, B. S., Ngo, K. M., Potts, M. D., and Lum, S. K. Y. (2013). Slow recovery of a secondary tropical forest in Southeast Asia. Forest Ecol. Manag. 308, 153-160. doi: 10.1016/j.foreco.2013.07.053

Cohen, A. L., Singhakumara, B. M. P., and Ashton, P. M. (1995). Releasing rain forest succession: a case study in the Dicranopteris linearis fernlands of Sri Lanka. Restor. Ecol. 3, 261-270. doi: 10.1111/j.1526-100X.1995.tb00093.x

Cox, E. S., Marrs, R. H., Pakeman, R. J., and Le Duc, M. G. (2007). A multi-site assessment of the effectiveness of Pteridium aquilinum control in Great Britain. Appl. Veg. Sci. 10, 429-440. doi: 10.1111/j.1654-109X.2007.tb00442.x

de Jesus Jatoba, L., Varela, R. M., Molinillo, J. M. G., Ud Din, Z., Juliano Gualtieri, S. C., Rodrigues-Filho, E., et al. (2016). Allelopathy of bracken fern (Pteridium arachnoideum): new evidence from green fronds, litter, and soil. PLoS One 11:e0161670. doi: 10.1371/journal.pone.0161670

DeLuca, T. H., Zewdie, S. A., Zackrisson, O., Healey, J. R., and Jones, D. L. (2013). Bracken fern (Pteridium aquilinum L. kuhn) promotes an open nitrogen cycle in heathland soils. Plant Soil 367, 521-534. doi: 10.1007/s11104-012-1484-0

Dolling, A. H. U. (1996). Interference of bracken (Pteridium aquilinum L. Kuhn) with scats pine (Pinus sylvestris L.) and Norway spruce (Picea abies L. karst.) seedling establishment. Forest Ecol. Manag. 88, 227-235. doi: 10.1016/S0378-1127(96)03846-7

Duan, W. J., Ren, H., Fu, S. L., Wang, J., Zhang, J. P., Yang, L., et al. (2010). Community comparison and determinant analysis of understory vegetation in six plantations in South China. Restor. Ecol. 18, 206-214. doi: 10.1111/j. 1526-100X.2008.00444.x

Gaudio, N., Balandier, P., Dumas, Y., and Ginisty, C. (2011). Growth and morphology of three forest understorey species (Calluna vulgaris, Molinia caerulea and Pteridium aquilinum) according to light availability. Forest Ecol. Manag. 261, 489-498. doi: 10.1016/j.foreco.2010.10.034 
Gordon, C., Woodin, S. J., Mullins, C. E., and Alexander, I. J. (1999). Effects of environmental change, including drought, on water use by competing Calluna vulgaris (heather) and Pteridium aquilinum (bracken). Funct. Ecol. 13(Suppl. 1), 96-106. doi: 10.1046/j.1365-2435.1999.00012.x

Guan, D. S. (2001). Dynamics of carbon in the grassland, fernland and shrubland of Hong Kong. Acta Ecol. Sin. 21, 440-445.

Hietz, P., Turner, B. L., Wanek, W., Richter, A., Nock, C. A., and Wright, S. J. (2011). Long-term change in the nitrogen cycle of tropical forests. Science 334, 664-666. doi: 10.1126/science.1211979

Hikino, H., and Hikino, Y. (1970). Arthropod molting hormones. Fortschr. Chem. Org. Naturst. 28, 256-312. doi: 10.1007/978-3-7091-7123-3_6

Hirota, M., Holmgren, M., Nes, E. H. V., and Scheffer, M. (2011). Global resilience of tropical forest and savanna to critical transitions. Science 334, 232-235. doi: 10.1126/science.1210657

Huan, Z. J., Su, J. S., and Zhang, Y. C. (1984). Measures and effects on the renovation of Dicranopteris linearis hilly land in South China. J. Fujian Agric. College 13, 47-52.

Ismail, B. S., and Chong, T. V. (2007). Effects of the extract of Dicranopteris linearis on seed germination and seedling growth of selected common weeds in Malaysia. Allelopath. J. 20, 287-296.

Jiang, J. (2013). Effects of Dicranopteris dichotoma on soil organic carbon pool during the revegetation of eroded red soil in subtropical China. Fujian Normal University, Fuzhou.

Jiang, M., Lin, T., Shaner, P., Lyu, M., Xu, C., Xie, J., et al. (2019). Understory interception contributed to the convergence of surface runoff between a Chinese fir plantation and a secondary broadleaf forest. J. Hydrol. 574, 862-871. doi: 10.1016/j.jhydrol.2019.04.088

Juma, G., Zhang, Y., Liu, Q., Yang, Y., Wang, X. P., Yang, S., et al. (2019). Allelopathic effects of native plant species Dicranopteris dichotoma on invasive species Bidens pilosa and Eupatorium catarium. Allelopath. J. 48, 45-58. doi: 10.26651/allelo.j/2019-48-1-1243

Kavitha, C. H., and Murugan, K. (2016). Dissimilitude response of peroxidases of Dicranopteris linearis (Burm.F.) Underw. against desiccation and rehydration stress. IOSR J. Biotechnol. Biochem. 2, 36-41.

Koyama, M., Shirakawa, M., Takada, J., Katayama, Y., and Matsubara, T. (1987). Trace elements in land plants: concentration ranges and accumulators of trace earths, $\mathrm{Ba}, \mathrm{Ra}, \mathrm{Mn}, \mathrm{Fe}, \mathrm{Co}$ and heavy halogens. J. Radioanal. Nucl. Chem. 112, 489-506. doi: 10.1007/BF02132381

Kubicka, K., Samecka-Cymerman, A., Kolon, K., Kosiba, P., and Kempers, A. J. (2015). Chromium and nickel in Pteridium aquilinum from environments with various levels of these metals. Environ. Sci. Pollut. Res. Int. 22, 527-534. doi: 10.1007/s11356-014-3379-5

Kuebbing, S. E., Reimer, A. P., Rosenthal, S. A., Feinberg, G., Leiserowitz, A., Lau, J. A., et al. (2018). Long-term research in ecology and evolution: a survey of challenges and opportunities. Ecol. Monogr. 88, 245-258. doi: $10.1002 / \mathrm{ecm} .1289$

Le Duc, M. G., Pakeman, R. J., and Marrs, R. H. (2007). A restoration experiment on moorland infested by Pteridium aquilinum: plant species responses. Agric. Ecosyst. Environ. 119, 53-59. doi: 10.1016/j.agee.2006.06.008

Lima, L. V., and Salino, A. (2018). The fern family Gleicheniaceae (Polypodiopsida) in Brazil. Phytotaxa 358, 199-234. doi: 10.11646/phytotaxa.358.3.1

Lin, X. X. (2004). The regulation of growth and development of Dicranopteris dichotoma and its propagative technology. Fujian Soil Water Conserv. 16, $60-62$.

Liu, Y. C., Liu, Q. J., Wang, H. Q., Ma, Z. Q., and Xu, W. J. (2008). Characteristics of biomass allocation of Dicranopteris dichotoma. Chinese J. Ecol. 27, 705-711.

Liu, H., Rakotondrainibe, F., Hennequin, S., and Schneider, H. (2020). The significance of Rouxopteris (Gleicheniaceae, Polypodiopsida): a new genus endemic to the Madagascan region. Plant Syst. Evol. 306, 1-11. doi: 10.1007/ s00606-020-01657-9

Liu, Z., Wu, J., Zhou, L., Lin, Y., and Fu, S. (2012). Effect of understory fern (Dicranopteris dichotoma) removal on substrate utilization patterns of culturable soil bacterial communities in subtropical Eucalyptus plantations. Pedobiologia 55, 7-13. doi: 10.1016/j.pedobi.2011.07.014

Mickel, J. T., and Smith, A. R. (2004). The pteridophytes of Mexico. Memoirs of the New York Botanical Garden. Acta Bot. Mex. 88, 1-1054. doi: 10.21829/ abm71.2005.1131

Milligan, G., Booth, K. E., Cox, E. S., Pakeman, R. J., Le Duc, M. G., Connor, L., et al. (2018). Change to ecosystem properties through changing the dominant species: impact of Pteridium aquilinum-control and heathland restoration treatments on selected soil properties. J. Environ. Manag. 207, 1-9. doi: 10.1016/j.jenvman.2017.11.013

Mitchard, E. T. A. (2018). The tropical forest carbon cycle and climate change. Nature 559, 527-534. doi: 10.1038/s41586-018-0300-2

Molino, J., and Sabatier, D. (2001). Tree diversity in tropical rain forests: a validation of the intermediate disturbance hypothesis. Science 294, 1702-1704. doi: 10.1126/science. 1060284

Negishi, J. N., Sidle, R. C., Noguchi, S., Nik, A. R., and Stanforth, R. (2006). Ecological roles of roadside fern (Dcranopteris curranii) on logging road recovery in Peninsular Malaysia: preliminary results. Forest Ecol. Manag. 224, 176-186. doi: 10.1016/j.foreco.2005.12.017

Pang, C. C., Ma, X. K., Pei-lai Lo, J. P., Hung, T. T., and Hau, B. C. (2018). Vegetation succession on landslides in Hong Kong: plant regeneration, survivorship and constraints to restoration. Glob. Ecol. Conserv. 15:e00428. doi: 10.1016/j.gecco.2018.e00428

Peng, H. H., Zheng, Z., Zheng, Y. W., Huang, K. Y., and Wei, J. H. (2015). Holocene vegetation changes and human activities revealed by a peat sediment core in Gaoyao, Zhaoqing. Quat. Sci. 35, 742-754. doi: 10.11928/j. issn.1001-7410.2015.03.24

Phillips, O. L., Malhi, Y., Higuchi, N., Laurance, W. F., Núñez, P. V., Vásquez, R. M., et al. (1998). Changes in the carbon balance of tropical forests: evidence from long-term plots. Science 282, 439-442. doi: 10.1126/science.282.5388.439

Pteridophyte Phylogeny Group (2016). A community-derived classification for extant lycophytes and ferns. J. Syst. Evol. 54, 563-603. doi: 10.1111/jse.12229

Ren, H., Li, Z. A., Shen, W. J., Yu, Z. Y., Peng, S. L., Liao, C. H., et al. (2006). Changes in biodiversity and ecosystem function during the restoration of a tropical forest in South China. Sci. China C Life Sci. 36, 563-569. doi: 10.1007/s11427-007-0028-y

Russell, A. E. (1996). The ecology of Dicranopteris linearis on windward Mauna Loa, Hawaii, U.S.A. Iowa State University, Ames.

Russell, G. B., and Fenemore, P. G. (1970). Insect moulting hormone activity of some New Zealand gymnosperms. N. Z. J. Sci. 13, 61-68.

Russell, A. E., Raich, J. W., and Vitousek, P. M. (1998). The ecology of the climbing fern Dicranopteris linearis on windward Mauna Loa, Hawaii. J. Ecol. 86, 765-779.

Russell, A. E., Ranker, T. A., Gemmill, C. E. C., and Farrar, D. R. (1999). Pattern of clonal diversity in Dicranopteris linearis on Mauna Loa, Hawaii. Biotrpioca 31, 449-459. doi: 10.1111/j.1744-7429.1999.tb00387.x

Senyanzobe, J. M. V., Mulei, J. M., Bizuru, E., and Nsengimuremyi, C. (2020). Impact of Pteridium aquilinum on vegetation in Nyungwe Forest, Rwanda. Heliyon 6:e04806. doi: 10.1016/j.heliyon.2020.e04806

Silva Matos, D. M., and Belinato, T. A. (2010). Interference of Pteridium arachnoideum (Kaulf.) Maxon. (Dennstaedtiaceae) on the establishment of rainforest trees. Braz. J. Biol. 70, 311-316. doi: 10.1590/s1519-69842010000200012

Slocum, M. G., Aide, T. M., Zimmerman, J. K., and Navarro, L. (2004). A strategy for restoration of montane forest in anthropogenic fern thichets in the Dominican Republic. Restor. Ecol. 14, 526-536. doi: 10.1111/j.1526100X.2006.00164.x

Slocum, M. G., Aide, T. M., Zimmerman, J. K., and Navarro, L. (2006). Natural regeneration of subtropical montane forest after clearing fern thickets in the Dominican Republic. J. Trop. Ecol. 20, 483-386. doi: 10.1017/S0266467404001646

Song, G., Feng, Y. S., Zhu, Q. P., Lu, M. X., Chen, D. Y., and Chen, Y. H. (2014). Dicranopteris dichotoma: a newly found radium and thoriumaccumulating plant. J. Guangzhou Univ. Natur. Sci. Ed. 13, 81-87.

Ssali, F., Moe, S. R., and Sheil, D. (2019). The differential effects of bracken (Pteridium aquilinum (L.) Kuhn) on germination and seedling performance of tree species in the African tropics. Plant Ecol. 220, 41-55. doi: 10.1007/ s11258-018-0901-8

Stewart, G., Cox, E., Duc, M. L., Pakeman, R., Pullin, A., and Marrs, R. (2008). Control of Pteridium aquilinum: meta-analysis of a multi-site study in the UK. Ann. Bot. 101, 957-970. doi: 10.1093/aob/mcn020

Sun, Z. Y., Ren, H., Schaefer, V., Lu, H. F., Wang, J., Li, L. J., et al. (2013). Quantifying ecological memory during forest succession: a case study from the lower subtropical forest ecosystems in South China. Ecol. Indic. 34, 192-203. doi: 10.1016/j.ecolind.2013.05.010

Sun, Z. Y., Wang, J., Ren, H., Guo, Q. F., Shu, J. W., and Liu, N. (2016). To what extent local forest soil pollen can assist restoration in subtropical China? Sci. Rep. 6:37188. doi: 10.1038/srep37188 
Testo, W., and Sundue, M. (2016). A 4000-species dataset provides new insight into the evolution of ferns. Mol. Phylogenet. Evol. 105, 200-211. doi: 10.1016/j. ympev.2016.09.003

Volkov, I., Banavar, J. R., He, F., Hubbell, S. P., and Maritan, A. (2005). Density dependence explains tree species abundance and diversity in tropical forests. Nature 438, 658-661. doi: 10.1038/nature04030

Walker, L. R. (1994). Effects of fern thickets on woodland development on landslides in Puerto Rico. J. Veg. Sci. 5, 525-532. doi: 10.2307/3235979

Walker, L. R., and Boneta, W. (1995). Plant and soil responses to fire on a fern-covered landslide in Puerto Rico. J. Trop. Ecol. 11, 473-479. doi: 10.1017/ S0266467400008981

Walker, L. R., and Sharpe, J. M. (2010). "Ferns, disturbance, and succession" in Fern ecology. eds. K. Mehltreter, L. R. Walker and J. M. Sharpe (Cambridge: Cambridge University Press), 177-219.

Wan, S., Zhang, C., Chen, Y., Zhao, J., Wang, X., Wu, J., et al. (2014). The understory fern Dicranopteris dichotoma facilitates the overstory Eucalyptus trees in subtropical plantations. Ecosphere 5, 1-12. doi: 10.1890/ES14-00017.1

Wang, X., Shan, X., Zhang, S., and Wen, B. (2003). Distribution of rare earth elements among chloroplast components of hyperaccumulator Dicranopteris dichotoma. Anal. Bioanal. Chem. 376, 913-917. doi: 10.1007/s00216003-2014-y

Wei, C. Y., Wang, C., Sun, X., and Wang, W. Y. (2007). Arsenic accumulation by ferns: a field survey in southern China. Environ. Geochem. Health 29, 169-177. doi: 10.1007/s10653-006-9046-0

Whitehead, S. J., Caporn, S. J. M., and Press, M. C. (1997). Effects of elevated $\mathrm{CO}_{2}$, nitrogen and phosphorus on the growth and photosynthesis of two upland perennials: Calluna vulgaris and Pteridium aquilinum. New Phytol. 135, 201-211. doi: 10.1046/j.1469-8137.1997.00651.x

Wu, J. R. (2008). Different adaptive responses to allelopathy and its implications for the invasion of Wedelia trilobata. South China Botanical Garden, Chinese Academy of Sciences, Guangzhou.

Wu, J. P., Liu, Z. F., Wang, X. L., Sun, Y. X., Zhou, L. X., Lin, Y., et al. (2011). Effects of understory removal and tree girdling on soil microbial community composition and litter decomposition in two Eucalyptus plantations in South China. Funct. Ecol. 25, 921-931. doi: 10.1111/j.1365-2435.2011.01845.x

Xie, J. S., Yang, Y., and Xie, M. (2006). Effects of vegetation restoration on carbon sequestration in degraded red soil. J. Soil Water Conserv. 20, 95-98.

Yang, L., Ren, H., Liu, N., and Wang, J. (2010). The shrub Rhodomyrtus tomentosa acts as a nurse plant for seedlings differing in shade tolerance in degraded land of South China. J. Veg. Sci. 21, 262-272. doi: 10.1111/j.1654-1103.2009.01140.x

Yang, S. X., Tian, Q. J., Liang, S. C., Zhou, Y. Y., and Zou, H. C. (2012). Bioaccumulation of heavy metals by the dominant plants growing in Huayuan manganese and lead/zinc mine land, Xiangxi. Environ. Sci. 33, 2038-2045.
Yang, L., Wang, J., Huang, Y., Hui, D., and Wen, M. (2014). Effects of the interception of litterfall by the understory on carbon cycling in Eucalyptus plantations of South China. PLoS One 9:e100464. doi: 10.1371/journal. pone.0100464

Yuan, Y. R., and Li, X. Y. (2007). Preliminary study on the mechanism of allelopathy in Dicranopteris pedata. J. Anhui Agric. Sci. 35, 5047-5048.

Yue, H. (2009). Study on the growth of Dicranopteris dichotoma and microbial population in different erosion soil. Forest Sci. Technol. 34, 22-26.

Yue, H., Zhong, B. L., Chen, Z. B., and Ruan, F. S. (2014). Colonization of Dicranopteris dichotoma and ecological reconstruction of eroded slopes. Subtrop. Soil Water Conserv. 26, 46-48.

Zhang, M. R., He, M., Wen, G. S., Zhang, R. M., Zhang, J. G., and Hou, P. (2010). The characteristics of Dicranopteris dichotoma population and its effects on the forest regeneration. J. Inn. Mong. Agric. Univ. 31, 303-308.

Zhang, K. M., Shi, L., and Li, Z. Y. (2004). Fern allelopathy and its impact on biodiversity. Biodivers. Sci. 12, 466-471. doi: 10.17520/biods.2004057

Zhao, H., Shao, Z., Yang, Y., Qiu, S., Lu, H., and Peng, S. (2007). Allelopathy of several common plants in South China on Mikania micrantha. Ecol. Environ. 16, 130-134.

Zhao, J., Wan, S., Li, Z., Shao, Y., Xu, G., Liu, Z. F., et al. (2012). Dicranopterisdominated understory as major driver of intensive forest ecosystem in humid subtropical and tropical region. Soil Biol. Biochem. 49, 78-87. doi: 10.1016/j. soilbio.2012.02.020

Zheng, H., Chen, F. L., Ouyang, Z. Y., Tu, N. M., Xu, W. H., Wang, X. K., et al. (2008). Impacts of reforestation approaches on runoff control in the hilly red soil region of Southern China. J. Hydrol. 356, 174-184. doi: 10.1016/j. jhydrol.2008.04.007

Zhu, S. D., Li, R. H., Song, J., He, P. C., Liu, H., Berninger, F., et al. (2016). Different leaf cost-benefit strategies of ferns distributed in contrasting light habitats of subtropical forests. Ann. Bot. 117, 497-506. doi: 10.1093/aob/ $\operatorname{mcv} 179$

Conflict of Interest: The authors declare that the research was conducted in the absence of any commercial or financial relationships that could be construed as a potential conflict of interest.

Copyright (C) 2021 Yang, Huang, Lima, Sun, Liu, Wang, Liu and Ren. This is an open-access article distributed under the terms of the Creative Commons Attribution License (CC BY). The use, distribution or reproduction in other forums is permitted, provided the original author(s) and the copyright owner(s) are credited and that the original publication in this journal is cited, in accordance with accepted academic practice. No use, distribution or reproduction is permitted which does not comply with these terms. 